\title{
RESEPSI EKSEGESIS UMAT ISLAM TERHADAP BUDAYA SEDEKAH (Studi Living Hadits di Masjid Sulthoni Wotgaleh, Sleman, Yogyakarta)
}

\author{
Muhammad Irsad \\ Fakultas Ushuluddin, Adab dan Dakwah, Institut Agama Islam Ma'arif Nahdlatul Ulama' Metro Lampung \\ e-mail: muhammadirsad1209@gmail.com
}

\begin{abstract}
Abstrak
Penelitian ini bertujuan mengungkap salah satu praktik budaya sedekah di Masjid Sulthoni Wotgaleh, Sleman, Yogyakarta. Sedekah yang dilakukan berupa uang, material bangunan sampai makanan dan minuman yang diperuntuke.ean bagi para jama'ah shalat jum'at. Penelitian ini berupaya menelusuri asal muasal munculnya praktik. sedekah tersebut, serta mengungkap resepsi eksegesis umat Islam terhadap hadits Nabi saw., yang menjadi akar teologis dari munculnya praktik sedekah tersebut. Hasil dari penelitian ini berkesimpulan babwa; pertama, asal muasal praktik sedekah yang terjadi di Masjï Sulthoni dilatarbelakangi oleh inisiatif umat Islam yang ingin mencari 'jalan alternatif' pendukung untuk terkabulnya permohonan atau keinginan. Kedua, terdapat tiga macam resepsi eksegesis umat Islam tentang bersedekah, yaitu sebgai wujud rasa syukur, sebagai penolak balak, dan sebagai sarana memperlancar rizki. Ketiga, sedekah yang membudaya dan ramainya masjid Sulthoni dikunjungi jamaah tidak bisa dipisabkan oleh sisi sakralitas makam Panembahan Purboyo I yang terletak di lingkungan masjid.
\end{abstract}

Kata Kunci: Sedekah, Living Hadits, Masjid Sulthoni.

\begin{abstract}
This study aims to reveal one of the practices of alms culture at Sulthoni Wotgaleh Mosque, Sleman, Yogyakarta. Alms made in the form of money, building materials to food and beverages intended for congregation prayers Friday. This study seeks to trace the origins of the emergence of alms practices, and reveal the exegesis of Muslims to the hadith of the Prophet, which became the theological root of the emergence of the practice of alms. The results of this study concluded that; first, the origin of the alms practices that took place at Sulthoni Mosque was motivated by the initiative of Muslims who wanted to find an 'alternative way' of supporters for their wishes or wishes to come true. Secondly, there are three kinds of exegesis receptions for Muslims about giving charity, which is a form of gratitude, as a repellent, and as a means of facilitating rizki. Third, the alms that entrenched and the crowded of the Sulthoni mosque visited by pilgrims could not be separated by the sacred side of the tomb of Panembahan Purboyo I located in the mosque.
\end{abstract}

Keywords: Alms, Living Hadith, Sulthoni Mosque.

\section{PENDAHULUAN}

Studi mengenai dua sumber utama dalam Islam yakni al-Qur'an dan Hadits selalu mengalami perkembangan dari masa kemasa. Dalam studi alQur'an, Amin al-Khulli sebagaimana dijelaskan oleh Abdul Mustaqim, membagi studi al-Qur'an ke dalam dua kelompok besar; dirasah ma fi Qur'an nafsih (studi tentang apa yanga ada di dalam alQur'an itu sendiri), dirasah ma hawla al-Qur'an (studi seputar al-Qur'an). Kedua studi inilah yang disebut oleh Abdul Mustaqim dengan studi "internal” dan "eksternal". (Abdul Mustaqim, 2017: 26). Seiring perkembangannya kemudian muncul lah studi lanjutan dari kedua studi terdahulu, yakni studi living Qur'an. Penulis berpendapat bahwa tipologi terhadap studi Qur'an tersebut adalah sama yang terdapat pada studi hadis. Termasuk kajian living yang kemudian dikenal dengan studi living hadis.

Jika mengacu pada pendapat di atas, studi living hadis merupakan studi baru jika dibandingkan dengan studi-studi sebelumnya. Oleh karena studi living hadis merupakan studi baru, maka sampai saat ini studi ini belum menemukan kedudukannya yang mapan, terutama pada sisi metodologis. Pendapat ini diperkuat oleh apa yang dikatakan oleh Muhammad Yusuf, bahwa formulasi metodologis living Qur'an (juga living hadis) menurut hemat saya masih mencari bentuk (form) yang dapat dijadikan semacam acuan, atau paling tidak cerminan ketika seseorang meneliti dan mengkaji bagaimana sesunguhnya model, metode dan prosedur yang harus ditempuh.(Muhammad Yusuf, 2007: 39). Namun, terlepas dari berbagai sisi studi living yang perlu terus untuk disempurnakan, 
setidaknya studi living ini bisa disadikan alternatif pilihan ditengah "kejenuhan" mahasiswa atau peneliti hadis yang sejak lama hanya berkutat pada teks.

Secara bahasa, living hadis berasal dari dua kata; living dan hadis. Dalam kamus bahasa Inggris, living adalah bentuk ajective dari kata kerja live yang berarti hidup. Living juga sering diberi makna yang bidup atau kehidupan.(H. Zuhri, 2018: 2). Maka, living hadis dapat didefinisikan sebagai hadis yang hidup di masyarakat. Dalam definisi lain Alfatih mengatakan, living hadis lebih di dasarkan atas adanya tradisi yang hidup di masyarakat yang disandarkan kepada hadis. (M. Alfatih Suryadilaga: 113). Dalam artikelnya, Alfatih juga merinci studi living hadis ini kedalam tiga tradisi, yaitu; tradisi tertulis, tradisi lisan dan tradisi praktik. (M. Alfatih Suryadilaga: 113). Tradisi yang ketiga atau tradisi praktik inilah yang akan dibahas dalam artikel ini.

Pada artikel ini, penulis ingin menyajikan sebuah penelitian living hadis yang membahas tentang resepsi eksegesis umat Islam tentang sedekah. Sebagaimana telah dipahami bahwa sedekah merupakan salah satu perbuatan yang sangat dianjurkan oleh Islam. Secara teologis, perintah sedekah banyak diiringi oleh janji balasan barupa pahala yang bersifat abstrak. Namun ibarat tanaman, sedekah dijanjikan sebagai perbuatan yang tidak hanya dapat dipetik buahnya kelak di akhirat namun juga bisa dirasakan dampaknya ketika masih berada di dunia.

Islam menjadikan sedekah sebagai ibadah yang sangat dianjurkan, bahkan Nabi Muhammad saw., telah memberikan contoh-contoh hal sederhana yang bernilai sedekah. Hal ini bisa kita lihat dalam sabda Nabi yang mengatakan bahwa, senyum, amar ma'ruf nahi munkar, menunjukkan jalan orang yang tersesat, sampai membersihkan benda yang menghalangi jalan juga dihitung sebagai sedekah:

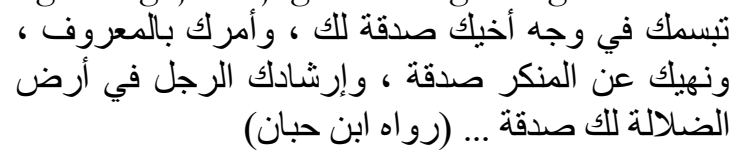

Artinya: "Senyummu dibadapan saudaramu adalah sedekah, perintahmu dengan cara yang baik dan mencegab dari perkara yang munkar adalah sedekah, petunjukmu terjadap seseorang yang tersesat adalah sedekah... (H.R. Ibn Hibban)

Sedekah dari segi esensi teologis tetaplah sama dari waktu ke waktu, hanya saja mengenai tekhnis pelaksanaan sedekah ini akan terus berkembang seiring menyebarnya Islam dan bersinggungan dengan tradisi dan budaya di masing-masing daerah. Demikian pula tradisi masyarakat Islam yang melakukan sedekah di Masjid Sulthoni Wotgaleh, tempat dimana penelitian ini dilakukan. Di Masjid Sulthoni Wotgaleh, terdapat macammacam barang yang disedekahkan oleh umat Islam. Ada yang berupa uang, makanan dan minuman bahkan ada sedekah yang berupa material bangunan seperti keramik, paving blok, dan pembangunan tempat parkir. Khusus untuk makanan dan minuman, biasanya dilakukan setiap hari jum'at, untuk dibagikan kepada para jamaah shalah jum'at.

Penulis memiliki tiga argumentasi atau uniqness yang melatarbelakangi ketertarikan penulis untuk melakukan studi living hadis di Masjid Sulthoni Wotgaleh; pertama, berdasarkan hasil observasi pratisipatif yang penulis lakukan, Masjid Sulthoni Wotgaleh ini berada sedikit memisah dari pemukiman warga, namun tetap ramai dikunjungi oleh para jamaah, sehingga menarik untuk dikaji apa yang melatarbelakangi fenomena tersebut. Kedua, dengan letak geografis yang demikian, justru di Masjid Sulthoni Wotgaleh menjadi tempat yang banyak dimanfaatkan masyarakat untuk menyalurkan sedekahnya. Seperti material bangunan, bahkan proyek pembangunan parkir masjid. Tidak hanya itu, penulis pernah mengamati sedekah uang yang diberikan jamaah banyak di dominasi uang pecahan 100.000 rupiah dan 50.000 rupiah, nominal ini termasuk besar untuk sedekah yang diberikan di masjid-masjid, atau jika dibandingkan dengan sedekah yang diberikan jamaah pada masjid-masjid yang lain. Ketiga, di belakang Masjid Sulthoni Wotgaleh ini, terdapat makam Panembahan Purbaya I yang disakralkan oleh masyarakat sekitar, sehingga penulis tertarik menganalisa adakah relasi antara resepsi masyarakat terhadap sedekah dengan sakralitas makam yang berada di belakang Masjid Suthoni Wotgaleh ini?

Untuk mendekati subjek penelitian, penulis menggunakan pendekatan historis-fenomenologis. Dalam hal ini, pendekatan fenomenologi yang penulis gunakan adalah pendekatan fenomenologi Kristensen. Sebagaimana dikutip Clive Erricker, Kristensen menyatakan, fenomenologi memiliki tugas mengelompokkan secara sistematik tentang karakteristik data untuk menggambarkan watak keagamaan manusia. Di sisi yang lain, fenomenologi secara langsung dapat terlibat 
dengan persoalan-persoalan heremenutik (pemaknaan). (Clive Erricker, 2002: 114). Dengan pendekatan fenomenologi ini, penulis akan menggunakannya dalam penggalian data untuk mengungkap wilayah pemaknaan (eksegesis) umat Islam terhadap sedekah.

Jika diterjemahkan kedalam rumusan masalah, maka rumusan masalah dalam penelitian ini dapat disusun sebagai berikut: 1) bagaimana resepsi umat Islam terhadap sedekah di Masjid Sulthoni Wotgaleh dan apakah yang melatarbelakanginya? 2) adakah pengaruh sakralitas makam Panembahan Purboyo I terhadap resepsi masyarakat tentang sedekah?

Sebagai pisau analisa yang akan penulis gunakan untuk membedah dua rumusan masalah di atas penulis menggunakan dua teori, yaitu: Teori Resepsi serta Teori Sakral dan Profan. Menurut Hans-Robert Jauss sebagaimana dikutip oleh Abdul Mustaqim, teori resepsi adalah sebuah versi dari teori sastra tentang respon pembaca yang menekankan pada resepsi atau penerimaan pembaca pada sebuah teks sastra. Secara umum, teori tersebut disebut dengan resepsi audien dalam analisis model komunikasi. (Abdul Mustaqim, 2017: 27-28). Kemudian Hans membagi teori resepsinya kedalam tiga ranah: pertama, ranah hermeneutis yang menekankan pada aspek pemaknaan dan tafsir. Kedua, ranah estetis yang menekankan pada aspek keindahan yang dapat berupa karya tulisan (rasm) dan suara. Ketiga, ranah sosio-kultural yang menekankan pada aspek tradisi dan budaya yang hidup di masyarakat. (Abdul Mustaqim, 2017: 27). Namun, Ahmad Rafiq lebih senang menggunakan istilah eksegesis daripada menggunakan istilah hermeneutik, karena menurutnya hermeneutik memiliki aturan-aturan yang baku sedangkan tidak dengan eksegesis. (Ahmad Rafiq, 2014: 147-154).

Teori kedua yang digunakan dalam penelitian ini adalah teori Sakral dan Profan. Teori Sakral dan Profan digagas oleh Mircea Eliade. Teori ini menyatakan bahwa, Yang Profan adalah bidang kehidupan sehari-hari, yaitu yang dilakukan secara teratur, acak dan sebenarnya tidak terlalu penting, mudah dihilangkan dan dilupakan. Yang Profan adalah tempat dimana manusia berbuat salah, selalu mengalami perubahan dan kadang dipengaruhi oleh chaos (kekacauan). Sedangkan Yang Sakral adalah wilayah supernatural, sesuatu yang ekstraordinasi, tidak mudah dilupakan, dan teramat penting. Yang Sakral adalah sesuatu yang abadi, penuh substansi dan realitas. Yang Sakral juga tempat dimana segala keteraturan dan kesempurnaan berada. (Daniel L. Pals, 2018: 281). Teori Yang Sakral ini banyak diasumsikan oleh pembaca Islam dan Kristen sebagai Tuhan yang personal, namun menurut Eliade Yang Sakral lebih luas dari hanya sekedar konsep tentang Tuhan yang personal. Yang Sakral bisa berarti kekuatan dewadewi, arwah para leluhur, jiwa-jiwa abadi atau kekuatan dari apa yang disebut penganut Hindu sebagai "Brahman". (Daniel L. Pals, 2018: 284). Oleh karena pemaknaan Yang Sakral begitu luas, Eliade mengatakan bahwa, pada mulanya apa saja yang berada dalam kehidupan ini yang bersifat biasa-biasa saja adalah bagian dari Yang Profan. Dia ada hanya untuk dirinya sendiri. Tapi, dalam waktu-waktu tertentu, hal-hal yang Profan dapat ditransformasikan menjadi Yang Sakral. (Daniel L. Pals, 2018: 292).

\section{METODE}

Pada penelitian ini metode penelitian yang digunakan adalah metode penelitian kualitatif lapangan (field qualitative research). Sedangkan metode pengumpulan data yang digunakan dalam penelitian ini ada tiga, yakni: metode dokumentasi, wawancara mendalam (dept interview), dan observasi partisipan.

Metode dokumentasi yang dimaksud disini adalah metode pengumpulan data yang dilakukan dengan cara mencari data tentang variabel penelitian dari berbagai macam dokumentasi, baik yang berupa catatan, transkip, buku, surat kabar, majalah, jurnal, dan lain sebagainya. (Suharsimi Arikunto, 1980: 62). Metode dokumentasi akan peneliti terapkan dalam melakukan studi pustaka, referensi teori-teori yang digunakan, dan sebagainya yang berkaitan dengan dokumen.

Observasi partisipan merupakan sebuah temuan metode inovatif dari seorang fungsionalis bernama Malinowski, dia hidup bersama masyarakat yang sedang diteliti, ambil bagian dalam aktivitas sehari-hari, belajar berbicara dengan mereka dengan bahasa mereka tanpa bantuan penerjemah, dan merekam segala sesuatu. Kemudian metode ini dikenal dengan observasi partisipan. (David N. Gelner, 2011: 26).

Sedangkan wawancara mendalam (depth interview) dimaksudkan untuk menggali riwayat hidup keagamaan informan sebagai warga 
masyarakat atau tokoh masyarakat, sehingga diharapkan dapat mengungkap baik pengalaman dan pengetahuan eksplisit maupun yang tersembunyi dibalik itu, termasuk informasi yang berkaitan dengan masa lampau, sekarang maupun harapan dan cita-cita keagamaannya di masa depan. (Abdul Mustaqim, 2007: 72).

Selain ketiga metode pengumpulan data tersebut, penulis menambahkan satu metode lagi untuk mendeskripsikan mendeskripsikan pemahaman atau resepsi umat Islam terhadap sedekah ini, penulis menggunakan metode "Lukisan Mendalam" (Thick Description) yang ditawarkan oleh Clifford Geertz. Metode ini terdapat dalam esai yang ditulis Geertz yang nantinya akan menajadi statemen klasik pokokpokok pemikirannya. Judul esai tersebut adalah "Thick Description: Toward an Interpretative Theory of Culture". Dalam esai tersebut, Geertz mengingatkan bahwa walaupun kata kebudayaan (culture) dipahami oleh para antropolog sebelumnya dengan arti berbeda-beda dan kunci untuk memahaminya adalah ide tentang makna (meaning, significance). Manusia, lanjut Geertz dengan mengutip Weber, adalah "hewan yang terkurung dalam jaring-jaring makna (signivicance) yang mereka pintal sendiri. Oleh karena itu, jika kita ingin melakukan apa yang telah diusahakan oleh para antropolog selama ini, yaitu menjelaskan kebudayaan orang lain, maka kita tidak punya pilihan kecuali menggunakan metode yang dinamakan oleh filsuf Inggris Gilbert Ryle dengan Thick Description. Kita harus melukiskan tidak saja apa yang secara aktual terjadi, tetapi bagaimana pemahaman seseorang tentang kejadian tersebut. (Daniel L. Pals, 2018: 408). Metode ini akan penulis gunakan untuk "melukiskan" makna terdalam dari sedekah yang dipahami, tidak hanya sebagai bentuk ibadah keagamaan (ubudiyyab) atau sebuah perilaku sosial, namun juga menggali dan mengungkap makna terdalam yang terkandung dalam sedekah itu sendiri.

\section{HASIL DAN PEMBAHASAN}

\section{Mengenal Masjid Sulthoni Wotgaleh.}

Masjid Sulthoni Wotgaleh terletak di dusun Noyokerten, Sendangtirto, Berbah, Sleman, tepatnya di sebelah selatan Bandara Adisucipto Yogyakarta. Masjid ini didirikan pada masa Mataram Islam, tahun $1600 \mathrm{M}$ dan dikenal sebagai salah satu Masjid Pathok. Negoro (batas negara). Selain berfungsi religius, juga sebagai tempat pertahanan rakyat. Di belakang masjid ini terdapat makam "Hastono Wotgaleh" tempat Panembahan Purubaya I (putera Panembahan Senopati Mataram) dan kerabatnya dimakamkan. (Himawan Prasetyo, 2017 dalam https://kebudayaan.kemdikbud.go.id/bpcbyogya karta/3314/). Makam Panembahan Purbaya ini dikenal sebagai salah satu tempat keramat di Yogyakarta. Masyarakat sekitar percaya, bahwa jika ada burung, kelelawar, bahkan pesawat yang melintasi atas makam Panembahan Purbaya maka akan jatuh. (Ihsyanul Majid, 2019: 92).

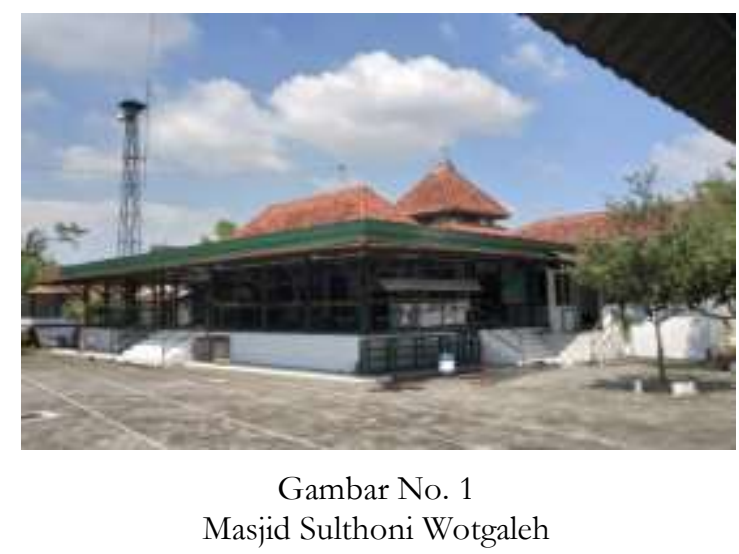

Berdasar pada observasi penulis pada 22 Maret 2019), secara geografis sebenarnya Masjid Sulthoni Wotgaleh terletak pada titik yang kurang strategis karena letaknya yang terpisah cukup jauh dari pemukiman warga dan dikelilingi oleh perkebunan tebu yang cukup luas. Dari sisi arsitektur, bangunan Masjid Sulthoni Wotgaleh menyerupai bangunan keraton khas Yogyakarta. Di samping halaman parkir yang cukup luas, terdapat dua batang pohon beringin besar semakin menegaskan khas keraton Yogyakarta. Saat memasuki ruang utama masjid, dapat disaksikan empat buah pilar yang terbuat dari balok-balok besar yang menjadi cirikhas masjidmasjid yang didirikan pada masa permulaan Islam di Jawa.

Namun, letak geografis yang kurang strategis ini nyatanya tidak mengurangi daya tarik umat Islam untuk datang melaksanakan ibadah di Masjid Sulthoni Wotgaleh. Selain masyarakat sekitar, Masjid Sulthoni Wotgaleh juga kerap dikunjungi oleh umat Islam diluar lingkungan Masjid. Hal ini bisa dibuktikan ketika shalat jum'at, lahan parkir yang cukup luas akan selalu dipenuhi oleh kendaraan-kendaraan baik roda dua maupun roda empat, (lihat lampiran). Selain sebagai tempat 
beribadah layaknya masjid-masjid pada umumnya, Masjid Sulthoni Wotgaleh juga dijadikan sebagai tempat kegiatan pengajian ibu-ibu dan tempat menyelenggarakan Taman Pendidikan Al-Qur'an (TPA), yakni TPA Al-Fatah. Sebagai masjid bersejarah, nampaknya Masjid Sulthoni Wotgaleh juga sangat menjaga tradisi-tradisi di masa lampau, misalnya melakukan pembacaan al-Qur'an secara manual oleh salah satu jamaah Masjid, dimana masjid-masjid pada umumnya saat ini lebih memilih memutar dari rekaman audio untuk memperdengarkan bacaan al-Qur'an.

\section{Akar Sejarah Sedekah di Masjid Sulthoni Wotgaleh.}

Berdasarkan hasil interview penulis kepaa pengurus Masjid Sulthoni, (Wawancara terhadap Bapak Muh, pada 22 Maret 2019), tidak bisa dipastikan sejak kapan sedekah ini bermula. Satusatunya informasi yang penulis dapatkan adalah, jamaah Masjid Sulthoni sekaligus peziarah di makam Panembahan Purboyo II banyak yang memberikan sedekah berupa uang, makanan, minuman baik yang diserahkan kepada pengurus masjid atapun yang diberikan kepada sesama jamaah masjid. Para jamaah yang memberikan sedekahnya tentu mempunyai tujuan dan harapan masing-masing, misalnya sekedar ingin berbagi rizki kepada sesama, atau memiliki harapan terkabulnya permohonan tertentu. Kemudian, atas kehendak Tuhan banyak jamaah yang merasa mendapatkan dampak postif setelah melakukan sedekah di Masjid Sulthoni Wotgaleh ini dan ceritanya sampai kepada pengurus masjid. Misalnya, ada yang mendapat kelancaran rizki, mendapat kenaikan pangkat, diterima sebagai Pegawai Sipil Negara (PNS), dan lain-lain.

Menurut Bapak Walid selaku informan, ada kemungkinan cerita-cerita semacam ini kemudian beredar dan berkembang di masyarakat sehingga menimbuklan keinginan untuk melakukan sedekah dengan harapan dan tujuan yang kurang lebih sama dengan para jamaah lain yang lebih dahulu melakukan sedekah. Menurut Bapak Walid, sedekah di Masjid Wotgaleh ini menjadi semacam budaya, yang tidak hanya dilakukan oleh orang yang memiliki keinginan tertentu namun juga dilakukan oleh orang yang merasa bahwa keinginannya telah terwujud. Dengan bersedekah, semakin besar keinginan yang terwujud semakin besar pula sedekah yang berikan. Misalnya, ada seorang jamaah yang menyumbang pemasangan keramik area samping kiri masjid secara keseluruhan, ada pula yang memberikan sedekahnya berupa pembangunan satu unit parkir indor yang ukurannya cukup besar dan bisa menampung ratusan kendaraan roda dua. (Wawancara terhadap Bapak Walid, 22 Maret 2019).

\section{Resepsi Eksegesis Umat Islam terhadap Sedekah.}

Sebagaimana telah penulis sebutkan pada bagian awal artikel ini, bahwa teori resepsi dapat dibedakan kedalam tiga ranah, yakni eksegesis, estetis dan kultural. Penulis lebih memilih menggunakan istilah eksegesis istilah yang digunakan oleh Ahmad Rafiq, karena eksegesis tidak membutuhkan aturan-aturan yang rumit dan baku dalam mememberikan pemaknaan ketika menerima sesuatu. Secara ringkas, resepsi eksegesis adalah penerimaan umat Islam terhadap sebuah teks hadis dari sisi pemaknaan, pemahaman atau penafsiran terhadap teks tersebut. Sedangkan resepsi estetis adalah penerimaan umat Islam terhadap hadis dari sisi estetika yang mengejawantah dalam karya seni, dan resepsi kultural adalah penerimaan umat Islam terhadap teks hadis yang melahirkan sebuah kultur atau budaya tertentu. Namun dalam artikel ini akan fokus pada resepsi eksegesis yang akan mengungkap penerimaan masyarakat terhadap pemaknaan dan pemahaman mereka tentang sedekah di Masjid Sulthoni Wotgaleh.

Untuk mendeskripsikan resepsi masyarakat terhadap sedekah, penulis menggunakan meode Thick Description, yaitu dengan melukiskan tidak saja apa yang secara aktual terjadi, tetapi bagaimana pemahaman seseorang tentang kejadian tersebut. Secara sepintas, kita dapat simpulkan bahwa sedekah merupakan perbuatan terpuji, baik dalam pandangan norma moral-sosial maupun secara dalam pandangan norma agama. Namun, dibalik perlaku baik menurut moral-sosial dan agama tersebut, bisa saja terdapat maksud terdalam yang disimpan oleh pelakunya, yakni semacam tujuanjujuan khusus yang menjadi alasan seseorang melakukan hal tersebut. Dengan cara ini lah, penulis akan menyajikan hasil wancara dengan pengurus masjid Sulthoni Wotgaleh tentang resepsi terhadap sedekah.

Pada saat pengumpulan data, sebenarnya penulis mendapatkan kesulitan untuk 
mewawancarai para pemberi sedekah dan mengungkap penerimaan atau pemaknaan mereka terhadap sedekah, karena hal tersebut merupakan wilayah privat. Kemudian penulis mewawancarai Bapak Walid selaku pengurus Masjid Sulthoni Wotgaleh. Dari Bapak walid inilah informasiinformasi seputar penelitian ini didapatkan. Sebagai pengurus, Bapak Walid mengatakan sering menerima penyerahan sedekah dengan berbagai macam motif dan tujuan, sebagai berikut:

1. Sedekah sebagai ungkapan rasa syukur.

Menurut Bapak Walid, sebagian besar pemberi sedekah di Masjid Sulthoni Wotgaleh adalah sebagai wujud rasa syukur atas nikmat yang telah diterima. Misalnya, karena mendapat kenaikan gaji, mendapat proyek besar, kenaikan pangkat, atau mendapatkan rejeki yang tidak disangka-sangka. Ungkapan rasa syukur ini kemudian diwujudkan dengan berbagi kepada sesama, biasanya dalam bentuk makanan atau minuman dan dilaksanakan berepatan dengan pelaksanaan ibadah shalat jum'at.

Praktik bersyukur dengan memberikan sesuatu kepada sesama memang sudah menjadi tradisi yang turun temurun bagi masyarakat Jawa, hal ini bisa dilihat dalam tradisi kenduri yang didalamnya terdapat sedekah pemberian makanan kepada para tetangga dan handai taulan. Wujud rasa syukur dengan memberikan sesuatu kepada sesama adalah ajaran dari Nabi Muhammad saw., yang menganjurkan umat Islam untuk bersyukur atau berterimakasih kepada manusia. Bahkan, dalam sebuah hadis dinyatakan bahwa ketiadaan syukur kepada manusia adalah ketiadaan syukur kepada Allah. من لم يشكر الناس لم يشكر الله (روه الترمذي فى الجامع

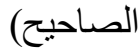

Artinya: "Barangsiapa yang tidak berterimakasih kepada sesama manusia maka ia (diangsap) tidak. bersyukur kepada Allah". (H.R. Tirmidzi dalam Jami' al-Shahih)

Sebenarnya, sedekah makanan dan minuman ini bukan satu-satunya tradisi yang berada di Masjid Sulthoni Wotgaleh ini, di bebrapa masjid di sekitar Wotgaleh seperti di Berbah juga ada yang melaksanakan tardisi demikian. Mungkin tradisi sedekah makanan dan minuman seperti ini akan sulit bahkan nyaris tidak ditemukan pada masjid-masjid di luat Yogyakarta, misalnya di Lampung daerah asal penulis, belum pernah menemukan tradisi yang demikian.

2. Sedekah sebagai penolak balak.

Menurut Bapak Walid, ada beberapa jamaah yang menyerahkan sedekahnya dengan tujuan sebagai penolak balak dan diberikan keselamatan. Mereka mempercayai bahwa dengan bersedekah bisa menghindarkan pemberi sedekah dari hal-hal yang tidak diinginkan, seperti penyakit, kecelakaan di jalan raya, kecelakaan kerja, dan lain sebagainya.

Salah satu manfaat beredakah adalah dapat menghindarkan dari balak dan mara bahaya. Hadis ini sangat populer di kalangan masyarakat, bahwa sedekah dapat menghindarkan 70 macam balak

$$
\text { الصدقة تطفع سبعين نو عا من البلاء (رواه الطبر اني) }
$$

Artinya: "Sedekah itu menolak tujuh puluh macam balak (musibah). (H.R. al-Thabarani)

Sedekah dengan tujuan semacam ini sudah lazim dilakukan oleh masyarakat Jawa. Dalam tradisi Jawa, ada istilah selametan (selamatan), genduren (kenduri) yang inti dari tradisi ini tidak jauh-jauh dari sedekah, dan sebagai ritual permohonan keselamatan.

3. Sedekah sebagai sarana memperlancar rizki.

Sebagian pemberi sedekah di masjid Sulthoni Wotgaleh bertujuan untuk memperlancar dalam upaya mencari rizki. Kelancaran dalam mencari rizki ini dapat dimaknai, misalnya pedagang yang menginginkan daganganya laris, pejabat yang ingin naik pangkat, petani yang menginginkan peningatan hasil panen atau wirausahawan yang ingin diperlancar urusannya.

Pemahaman tentang sedekah sebagai sarana memperlancar rizki memang merupakan salah satu ajaran yang bersumber dari Rasul Muhammad saw., dalam hadisnya

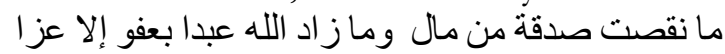

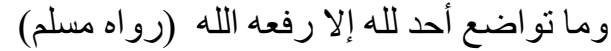

Artinya: "Sedekah tidak akan mengurangi harta, dan Allah tidak akan menambabkan kepada hamba yang pemaaf kecuali kemulyaan dan tidake ada seorangpun yang rendah hati kecuali Allah akan mengangkat derajatnya. (H.R. Muslim)

Petikan hadis di atas berarti "sedekah tidak akan mengurangi dari harta". Pemahaman sebaliknya (mafhum mukhalafah) dari petikan hadis tersebut adalah "harta justeru akan bertambah bila disedekahkan". Atas dasar 
pemahaman inilah, sebagian umat Islam meresepsi sedekah sebagai sarana dalam memperlancar rizki.

Relasi Sedekah di Masjid Sulthoni dan Sisi Sakral Makam Panembahan Purbaya I.

Masjid Sulthoni Wotgaleh adalah salah satu masjid yang telah secara resmi menjadi Cagar Budaya dan dilindungi oleh undang-undang pada tahun 2010, dan baru pada tahun 2014 Masjid Sulthoni terdaftar sebagai salah satu warisan budaya Kabupaten Sleman. Dibelakang masjid Sulthoni ini terdapat area pemakaman Panembahan Purbaya, yang menjadi Senopati pada masa awal kerajaan Mataram Islam yang dipimpin oleh Sultan Agung Hanyokrokusumo. Bagi masyarakat jawa, sebenarnya bukan hal baru ada masjid yang didekatnya dijadikan makam, hal seperti ini bisa dengan mudah ditemui di banyak tempat. Namun, yang menjadikan beda adalah siapa yang dimakamkan di lingkungan masjid tersebut? Di masjid Sulthoni, yang dimakamkan adalah Panembahan Purbaya I yang semasa hidupnya dikenal masyarakat sebagai seorang yang sangat sakti, sehingga oleh Sultan Agung diangkat sebagai senopati.

Sebagaimana telah penulis sebutkan pada pertengahan artikel ini, bahwa teori Sakral dan Profan Eliade menyatakan bahwa Sakral tidak hanya merujuk pada makna Tuhan dan atau kalamNya. Yang Sakral bisa berarti kekuatan dewa-dewi, arwah para leluhur, jiwa-jiwa abadi atau kekuatan dari apa yang disebut penganut Hindu sebagai "Brahman". (Daniel L. Pals, 2018: 284). Persepsi terhadap Yang Sakral yang menyangkut arwah para leluhur ini, nampaknya masih diprcayai oleh sebagian umat Islam jamaah Masjid Sulthoni Wotgaleh. Masyarakat sekitar percaya bahwa jika ada sesuatu yang melitas di atas makam Panembahan Purbaya I maka sesuatu tersebut akan jatuh dalam keadaan mati. Misalnya burung, kelelawar, bahkan pesawat terbang.

Perspsi masyarakat yang menganggap sakral makam Panembahan Purboyo I, dapat dilihat pada malam-malam tertentu misalnya malam senin kliwon (ada yang mengatakan malam selasa kliwon) sebagai hari kelahiran Panembahan Purboyo dan malam jumat kliwon sebagai malam yang dianggap keramat oleh masyarakat. Pada malam-malam tersebut, makam Panembahan Purboyo sangat ramai dikunjungi oleh para peziarah. Hasil interview penulis menunjukkan, pelaksanaan ziarah di makam Panembahan Purboyo dilakukan dengan dua cara; bisa dengan cara individu dan bisa pula dengan cara berjamaah. Jika dengan berjamaah biasanya akan diimami oleh salah seorang yang ditunjuk oleh pengurus masjid.

Menurut Bapak Walid, banyak dari para peziarah yang mengisahkan terkabulnya hajat mereka setelah melakukan ziarah di makam Panembahan Purboyo I. Kemudian, sebagai ungkapan kegembiraan para peziarah biasanya memberikan sedekah dengan wujud sedekah yang bermacam-macam. Menurutnya, ada kemungkinan cerita-cerita positif inilah yang berkembang di masyarakat sehingga setidaknya menyebabkan dua hal; pertama, masjid Sulthoni menjadi masjid yang banyak dikunjungi jamaah meskipun secara geografis masjid Sulthoni berada di area perkebunan tebu dan memisah dari pemukiman masyarakat, dan kedua, banyak jamaah yang memberikan sedekahnya di Masjid Sulthoni Wotgaleh ini.

\section{PENUTUP}

Dari hasil pembahasan yang telah dilakukan, penulis berkesimpulan bahwa jamaah Masjid Sulthoni Wotgaleh memiliki tiga resepsi eksegesis terhadap sedekah, pertama, sedekah sebagai wujud syukur atas karunia yang telah diterima; kedua, sedekah sebagai penolak balak, dan ketiga, sedekah sebagai sarana dalam memperlancar rizki. Banyaknya jamaah yang mengunjungi masjid Sulthoni dan budaya sedekah yang tercipta, tidak bisa dilepaskan dari sisi sakralitas yang terdapat pada makam Panembahan Purboyo I yang terletak di lingikungan masjid. Sebagian masyarakat mempercayai kesakralan makam Panembahan Purboyo, sehingga bersedekah di masjid Sulthoni menjadi (dianggap) berbeda jika dilakukan di masjid-masjid yang lain.

\section{DAFTAR PUSTAKA}

Arikunto, Suharsimi, Prosedur Penelitian: Suatu Pendekatan Praktek, (Jakarta: Bina Usaha, 1980).

Erricker, Clive, Pendekatan Fenomenologi, dalam Peter Connolly, Aneka Pendekatan Studi Agama, (Yogyakarta: LkiS, 2002). 
Gelner, David N., Pendekatan Antropologi, dalam Peter Conolly (ed.) Aneka Pendekatan Studi Agama (terj.) (yogyakarta: LkiS Group, 2011).

Majid, Ihsyanul, Pembacaan Ayat-Ayat Al-Qur'an dalam Tradisi Ziarah Kubur di Wotgaleh (Studi Lving Qur'an), Skripsi, (Yogyakarta: UIN Sunan Kalijaga, 2019).

Mustaqim, Abdul, Metode Penelitian Al-Qur'an dan Hadis, (Ypgyakarta: Idea Press, 2017).

Mustaqim, Abdul, Metode Penelitian Living Qur'an: Model Penelitian Kualitatif, dalam Sahiron Syamsuddin (ed.) Metodologi Penelitian Living Qur'an dan Hadis, (Yogyakarta: TH-Press, 2007).

Pals, Daniel L., Seven Theories of Religion: Tujuh Teori Agama Paling Berpengaruh, terj. (Yogyakarta: IRCiSoD, 2018).

Prasetyo, Himawan, Masjid Sulthoni Wotgaleh, 2017 , dalam https://kebudayaan.kemdikbud.go.id/bpcby ogyakarta/3314/, diakses pada 20 Maret 2019.

Rafiq, Ahmad, The Reception of The Qur'an In Indonesia: A Case Study of The Place of The Qur'an in Non-Arabic Speaking Community, Disertasi. Tempel University, 2014.

Suryadilaga, M. Alfatih, Model-Model Living Hadis, dalam Sahiron Syamsuddin, (ed.) Metodologi Penelitian Living Qur'an dan Hadis, (Yogyakarta: Teras).

Yusuf, Muhammad, Pendekatan Sosiologis dalam Penelitian Living Qur'an, dalam Sahiron Syamsuddin, (ed.) Metodologi Penelitian Living Qur'an dan Hadis, (Yogyakarta: Teras).

Zuhri, H., "Living Islam: Apa dan Mau Kemana?", dalam Jurnal Living Islam, Vil. 1, No. 1, Juni 2018.

Interview dilakukan kepada Bapak Muh, pada 22 Maret 2019.
Interview dilakukan kepada Bapak Walid, pada 22 Maret 2019. 